\title{
Preliminary report on the effect of ketamine in patients with central pain
}

\author{
Sylvie Rostaing-Rigattieri MD, Pierre Cesaro MD PhD, Jean-Paul N'Guyen MD, Jean-François Ejzenbaum MD, \\ Bernard Pollin PhD, Francis Bonnet MD
}

\section{S Rostaing-Rigattieri, P Cesaro, J-P N'Guyen, J-F Ejzenbaum, B Pollin, F Bonnet. \\ Preliminary report on the effect of ketamine in patients with central pain.}

Pain Res Manage 1997;2(2):95-100.

This preliminary open prospective study reports on the effect of ketamine, an N-methyl-D-aspartate (NMDA)-receptor noncompetitive antagonist, in five patients suffering from central poststroke pain (CPSP). Patients were evaluated at rest on a visual analogue scale (VAS) graded from 0 to 10 . Pain measurement was repeated at 15 and 30 mins following intravenous administration of 0.15 to $0.25 \mathrm{mg} / \mathrm{kg}$ ketamine and then every $30 \mathrm{mins}$ for $6 \mathrm{~h}$. Pain evoked by light touch or cold stimulation was also measured in three patients at those times. Patients were monitored for arterial pressure, heart rate, sedation and side effects during the study. Ketamine provided a significant improvement in pain at rest and in evoked pain. A $51 \%$ to $84 \%$ decrease in the VAS score for pain at rest was observed within 60 to 180 mins. Satisfactory pain relief (more than 50\% decrease in the VAS score) lasted for 150 to 210 mins. Two patients had a prolonged improvement over two or three days. Arterial pressure and heart rate did not change significantly. Mild or moderate sedation was noticed in all patients for 20 to 30 mins. These results suggest that blockade of NMDA receptors may provide pain relief in patients suffering from CPSP.

Key Words: Central pain, Central poststroke pain, Ketamine, N-methyl-D-aspartate (NMDA) antagonists, Thalamic pain

\section{Etude preliminarie : Effet de la ketamine chez des patients souffrant de douleurs neuropathiques d'origine centrale}

RÉSUMÉ : Cette étude prospective ouverte porte sur l'effet de la kétamine, un antagoniste des récepteurs N-methyl-D-aspartate (NMDA), non compétitif, chez cinq patients souffrant de douleurs neuropathiques centrales après accident vasculaire cérébral, ischémique ou hémorragique. La douleur est évaluée sur une échelle visuelle analgique (EVA) de 0 à 10 avant l'injection, puis 15 et 30 minutes après l'administration intraveineuse de 0,15 à $0,25 \mathrm{mg} / \mathrm{kg}$ de kétamine, puis toutes les 30 minutes pendant 6 heures. La douleur évoquée au toucher ou au froid est également évaluée chez 3 patients, avec la même séquence. La pression artérielle, la fréquence cardiaque, la sédation et les effets secondaires sont surveillés pendant la durée de l'étude. La kétamine entraîne use diminution significative de la douleur spontanée et de la douleur évoquée. Un effet antalgique maximal de 51\% à 84\% est observé entre 60 et 180 minutes après l'administration de kétamine. 3 patients ont un effet antalgique satisfaisant de plus de $50 \%$ pendant 150 à 210 minutes. 2 patients ont un post-effet de 2 à 3 jours. Il n'est pas observé de modification significative de la pression artérielle et de la fréquence cardiaque. Chez tous les patients une sédation légère à mondérée est notée pendant 20 à 30 minutes. Ces résultats suggèrent que le blocage des récepteurs NMDA peut entraîner un effet antalgique chez les patients souffrant de douleurs neuropathiques centrales survenant après accident hémorragique ou ischémique cérébral.
$\mathrm{C}$ entral poststroke pain (CPSP) is a chronic neuropathic pain syndrome commonly resistant to pharmacological treatments and techniques. Allodynia, dysesthesia, hyperalgesia and sensory loss are frequently noticed in patients suffering from CPSP (1-4). In peripheral neuropathic pain, allodynia and hyperalgesia are symp- toms related to plastic changes within the nervous system, resulting in peripheral and spinal cord sensitization (5-8) that could be mediated by N-methyl-D-aspartate (NMDA) receptor stimulation (9-17). Even if most NMDA receptors are located at the spinal cord level (18-20), NMDA receptors are also involved in synaptic transmis-

Département d'Anesthésie-Réanimation, Service de Neurologie, Service de Neurochirurgie, Hôpital Henri Mondor; INSERM U421, Faculté de Médecine, Cedex, France; Laboratoire de physiologie de la Manducation, Université Paris VII, Paris, France

Correspondence: Dr S Rostaing-Rigattieri, Département d'Anesthésie Réanimation, Hôpital Henri Mondor, 51 avenue du Maréchal de Lattre de Tassigny, 94010 Creteil, Cedex, France. Telephone 33-14-981-2381, fax 33-14-981-2380

Received for publication October 8, 1996. Accepted January 23, 1997 
sion in several brain areas such as the hippocampus and visual cortex $(21)$ or ventrobasal thalamus $(22,23)$. Blocking the NMDA receptor system might therefore provide pain relief in patients suffering from central pain syndrome. Ketamine is an NMDA receptor noncompetitive antagonist used as an anesthetic agent $(24,25)$. It also has analgesic effects, even in subanesthetic doses (26-32). Analgesic effects of ketamine have been documented in case reports from patients with peripheral neuropathic pain (33), CPSP (33), phantom limb pain $(34)$, chronic orofacial pain $(35,36)$ and postherpetic neuralgia (37), and nociceptive pain in control subjects (38).

In this report we describe our assessment of the analgesic effect of ketamine in five patients suffering from CPSP.

\section{PATIENTS AND METHODS}

This study was an open prospective trial of intravenous ketamine in patients with CPSP. All patients were referred to ketamine testing after informed consent. They all suffered from documented CPSP lasting several months or years following hemispheric hematoma or infarction. CPSP was associated with allodynia, hyperalgesia or both. All patients were treated unsuccessfully with tricyclic antidepressants, neuroleptics and/or antiepileptics. Three of the five patients were premedicated with $1 \mathrm{mg}$ lorazepam $1.5 \mathrm{~h}$ before the injection of ketamine.

Ketamine ( $100 \mathrm{mg}$ in $10 \mathrm{~mL}$ ) was diluted in $50 \mathrm{~mL}$ isotonic solution and a 0.15 to $0.25 \mathrm{mg} / \mathrm{kg}$ dose was administered intravenously over 10 mins. In one patient (patient 1), a single-blind placebo test (isotonic saline intravenous injection) was performed 30 days after ketamine administration.

Patients were previously evaluated at rest on a visual analogue scale (VAS) graded from 0 to 10 . Pain measurement was repeated at 15 and 30 mins following intravenous administration and then every 30 mins for $6 \mathrm{~h}$. During this period patients were monitored for arterial pressure, heart rate and sedation using a five-point scale (1: patient awake, normal vigilance; 2 : patient mildly drowsy; 3 : patient moderately drowsy requiring verbal stimulation; 4 : patient markedly drowsy, only reactive to nociceptive stimulation; 5: patient reactive). Other side effects were also recorded. Pain evoked by light touch or cold stimulation of the corresponding cutaneous field was measured by VAS in three cases. VAS scores were analyzed using Wilcoxon test and are presented as medians and percentiles. $\mathrm{P}<0.05$ was considered significant.

\section{CASE PRESENTATIONS}

\section{Patient 1}

Patient 1 was a 66-year-old man who suffered from a right thalamic hematoma, documented on computed tomography (CT) scan, resulting in transient left hemiparesis. Six months later he complained of a burning pain sensation in the left arm and leg, and in the left side of the face. Pain in the left foot increased in the standing position. Pain increased in severity over four years; several pharmacological treatments, including carbamazepine, levodopa, intravenous lidocaine, levomepromazine, tricyclic antidepressants, amitriptyline and clomipramine, failed to achieve any substantial relief.

On examination he complained of allodynia to light touch, which was worst in the left upper and lower extremities and was not followed by a painful 'after-sensation'. Just before ketamine administration, pain was severe enough to compromise walking. At that time his treatment comprised clomipramine, bromazepam and amitriptyline.

\section{Patient 2}

Patient 2, a 56-year-old woman, suffered from aneurysmal subarachnoid hemorrhage. She underwent emergency aneurysmal surgery but four days later developed a right hemiparesis related to a vasospasm. Magnetic resonance imaging and CT scan documented a small ischemic left thalamic lesion and an ischemic centrum ovale stroke. Two years later she developed pain in the right half of the body with a severe paroxysmal crisis, described as a sensation of compression and stiffness, mostly located in the right leg and shoulder. Pain was resistant to clomipramine and transcutaneous electrical nerve stimulation (TENS); cortical stimulation also failed to control it.

On examination she had a mild gentle sensory deficit to light touch and pinprick, but no allodynia, hyperalgesia or dysesthesia. Treatment, prior to ketamine injection, consisted of bromazepam, oxazepam, baclofen and amitriptyline.

\section{Patient 3}

Patient 3 was a 47-year-old woman. Transient aphasia and right hemiparesis occurred once in 1990 and twice in 1991 following a stroke in the middle cerebral artery area. CT scan showed left frontal and parietal infarcts. One week after the third stroke she developed a severe continuous burning pain sensation associated with paroxysms in the right hemiface, shoulder and arm, and in the lateral part of the thorax.

On examination she had allodynia to light touch with brief painful after-sensation, weakness of the right arm and sensory deficit in the right part of the chin. During a three-year period she underwent TENS and acupuncture, and received several drugs including clomipramine, amitriptyline, fluoxetine, carbamazepine, clonazepam and buprenorphine, which all failed to provide symptom relief. Before ketamine administration she had stopped administration of all the drugs for at least one year.

\section{Patient 4}

Patient 4, a 66-year-old man, had a history of arterial hypertension, duodenal peptic ulcer and prostatic adenocarcinoma. In June 1989 he suffered from right hemiparesis. CT scan revealed a left thalamic hematoma related to an intracranial cavernoma. A continuous burning sensation and dysesthesia in the right hand occurred one month later. Light touch produced unbearable paresthesiae. Pain was permanent but was worst at the beginning and end of the day. There had been no change in the intensity of pain for years despite intensive pain treatment including injection of corticosteroids in the carpal tunnel, amitriptyline, imipramine, TENS, clomipramin, oxitriptan, capsaicine ointment, intravenous lidocaine and chloroformeacetylsalicylic acid topical application. Pain was only relieved by cold or tepid water on the area. Before the ketamine test he was treated with clonazepam and zopiclone.

\section{Patient 5}

Patient 5 was a 59-year-old woman with a history of ophthalmic migraine, basilar artery insufficiency syndrome, arterial hypertension and stable angina. She suffered from a right middle cerebral artery 
stroke, confirmed by CT scan, resulting in a left transient hemiplegia. Three months later she developed pain and hyperalgesia in the left half of her body. She described her pain as a hot and burning sensation located mostly in the left part of the face, and the left hand, thigh and knee. Examination revealed a left hemiparesis, hyperalgesia and hyperpathia to cold and light touch. Evoked pain was followed by a prolonged painful after-sensation. She also complained of prolonged burning pain when her hand was dipped into cold water. An ice cube placed on her left wrist resulted in an immediate severe pain sensation followed by a pronounced increase in the basic pain level, expanding to the left side of her body. Evoked pain might last more than $12 \mathrm{~h}$ after termination of stimulation. Moderate pain relief had been achieved with clomipramine, methysergide, clonazepam and piracetam. She proceeded with this treatment until administration of ketamine.

\section{RESULTS}

As documented in Figure 1, ketamine provided a significant decrease in VAS scores in pain at rest. In all patients the onset time of pain sedation was close to 15 mins. In patients 1 and 2, a decrease in pain scores of $69 \%$ and $71 \%$, respectively, was observed at 60 mins. In patient 3 , ketamine administration produced a $84 \%$ decrease in pain at 120 mins. Patient 4 had a $51 \%$ maximum pain relief at 180 mins. The maximum effects of intravenous ketamine were therefore observed within 60 to 180 mins and ranged between $51 \%$ and $84 \%$. Patient 5 had no pain at rest. Pain scores at rest progressively increased to values measured before ketamine administration at 330 to 360 mins in patients 1,2 and 3. Pain sedation was reported to last two days in patient 4 .

A significant improvement was also noticed in evoked pain (Figure 2) and in postsensitization evoked phenomena. Pain evoked by cold stimulation was completely abolished within 15 mins in patient 5 . This patient had no more evoked pain sensation during the following three days. The other two patients (patients 1 and 3) had satisfactory evoked pain relief (greater than 50\%) for 150 to 210 mins, after which pain scores progressively increased to values comparable with those preceding drug administration (at 210 mins for patient 1 and after 360 mins for patient 3) (Figure 2). No significant effect on VAS score was observed in patient 1 after isotonic saline intravenous administration.

Arterial blood pressure and heart rate did not change significantly during the study period.

Side effects, observed from the start of the analgesic effect in all patients, lasted 20 to 30 mins. Side effects included mild or moderate sedation (ratings of 2 to 3 on the sedation scale) for all patients, and sensation of warmth, numbness, singing noises and feeling of detachment from the body, for some patients.

\section{DISCUSSION}

This open study points out a significant analgesic effect of intravenous ketamine in patients with CPSP. The five patients described here were given ketamine as a sedative in an unblinded manner, having been informed about the possible analgesic effect of the drug and the transient side effects; therefore a placebo effect cannot be ruled out. Considering that these patients had a long history of unsuccessful therapeutic attempts, it is nevertheless unlikely that a placebo effect could explain the striking decrease in VAS scores

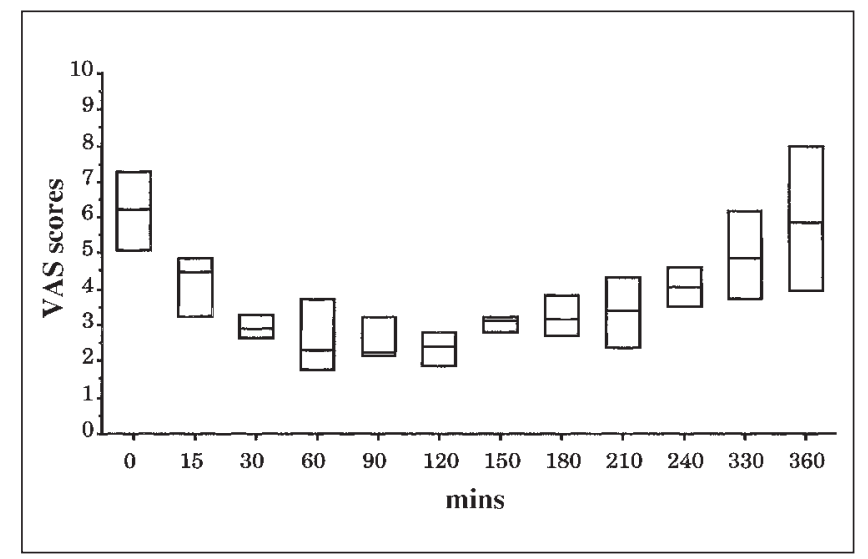

Figure 1) Pain at rest before and after intravenous administration of ketamine measured using a visual analogue scale (VAS) in four patients. Data are median; boxes represent the 25 th and 75 th percentiles

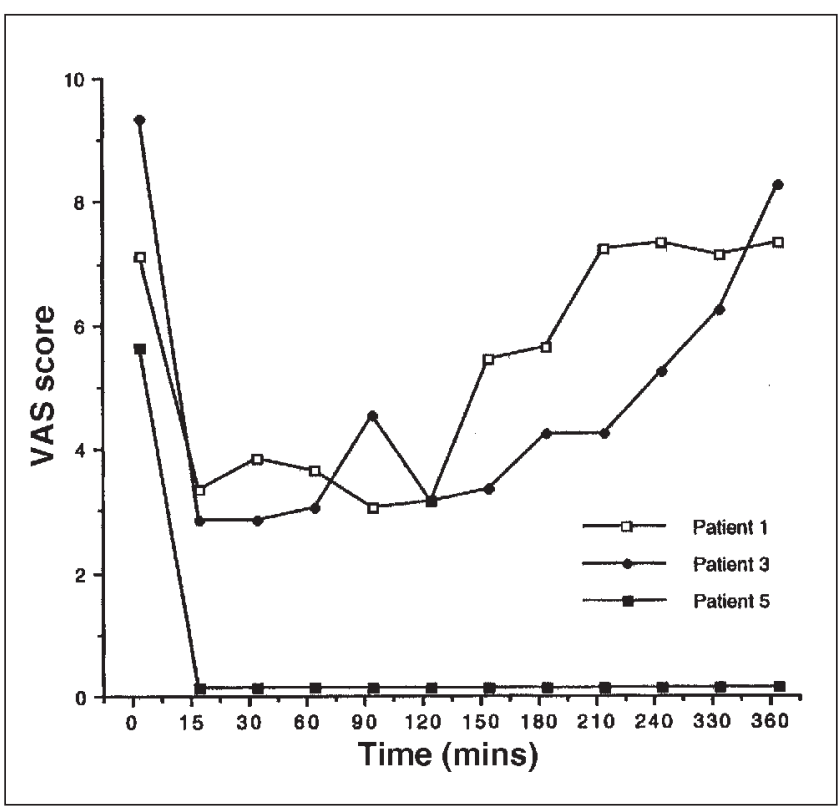

Figure 2) Individual changes in evoked pain after ketamine administration in patients 1, 3 and 5 . In patient 1 pain was evoked in the foot by the standing position, in patient 3 it was evoked by gentle touch of the right arm and in patient 5 by cold stimulation on the wrist. VAS Visual analogue scale

noted in this study. Another argument supports the hypothesis of a pharmacological rather than a placebo effect: the low variability of the time course and duration of analgesia.

Backonja et al (33) reported that intravenous ketamine induced analgesia in patients with peripheral $(n=3)$ or central pain syndrome $(n=3)$. They described that ketamine had less effect on ongoing pain than on evoked pain and the associated after-sensation. Unlike results from the study of Backonja et al, subanesthetic doses of ketamine produced, in our five patients, an improvement in evoked pain, allodynia, hyperalgesia or dysesthesia as well as a spontaneous pain relief.

Conversely, in agreement with results from Backonja and colleagues, we report that 0.15 to $0.25 \mathrm{mg} / \mathrm{kg}$ of intravenous ketamine produced satisfactory analgesia for 2 to $3 \mathrm{~h}$. After that, pain relief 
persisted at a lower degree, and two patients had a prolonged incomplete analgesic effect for a few days. We also observed side effects previously described with the use of ketamine; they were transient, well tolerated and never required any treatment, but they may be a concern for CPSP chronic treatment. No relationship was documented between the ketamine dose and the decrease in VAS score, but the three different doses of ketamine were not evaluated in all patients. The series and the dose range are too limited to allow a definite conclusion on that point.

Pathogenesis and characteristics of pain are different from one patient to another; therefore response to ketamine is variable and possibly independent of minor change in dose.

Mathisen et al (36) studied the effect of ketamine in seven patients suffering from chronic orofacial pain. Ketamine had some analgesic effect in the four patients who had suffered for more than five years and had no effect in the three who had pain for less than three years. The lowest dose of ketamine used in that study was 0.4 $\mathrm{mg} / \mathrm{kg}$, higher than the doses administered in our study.

\section{REFERENCES}

1. Fields HL. Painful dysfunction of the nervous system. In: HL Fields, ed. Pain. New York: McGraw-Hill, 1987:133-70.

2. Boivie J, Leijon G. Clinical findings in patients with central post-stroke pain, In: Casey KL, ed. Pain and Central Nervous System Disease. New York: Raven, 1991:65-75.

3. Woolf CJ, Chong MS. Preemptive analgesia. Treating postoperative pain by preventing the establishment of central sensitization. Anesth Analg 1993;77:362-79.

4. Boivie J. Central pain. In: Wall PD, Melzack R, eds. Textbook of Pain. Edinburgh: Churchill-Livingstone, 1994:871-902.

5. Seltzer Z, Beilin B, Ginzburg R, Paran Y, Shimko T. The role of injury discharge in the induction of neuropathic pain behaviour in rats. Pain 1991;46:327-36.

6. LaMotte RH, Shain CN, Simone DA, Tsai E, Fun P. Neurogenic hyperalgesia: psychophysical studies of underlying mechanisms. J Neurophysiol 1991;66:190-211.

7. Owens CM, Zhang D, Willis WD. Changes in the response states of primate spinothalamic tract cells caused by mechanical damages of the skin or activitation of descending controls. J Neurophysiol 1992;67:1509-27.

8. Yaksh TL, Abram SE. Preemptive analgesia. A popular misnomer, but a clinically relevant truth? Am Pain Soc J 1993;2:116-21.

9. Yaksh TL. Behavioral and autonomic correlates of the tactile evoked allodynia produced by spinal glycine inhibition: effects of modulatory receptor systems and excitatory amino-acid antagonists. Pain 1989;37:111-23.

10. Woolf CJ. Recent advances in the pathophysiology of acute pain. Br J Anaesth 1989;63:139-46.

11. Dickenson AH. A cure for wind up: NMDA receptor antagonists as potential analgesics. TIPS 1990;11:307-9.

12. Haley JE, Sullivan AF, Dickenson AH. Evidence for spinal $\mathrm{N}$-methly-D-aspartate receptor involvment in prolonged chemical nociception in the rat. Brain Res 1990;518:218-26.

13. Woolf CJ, Thompson WN. The induction and maintenance of central sensitization is dependent on N-methyl-D-aspartate acid receptor activation: implication for the treatment of post-injury hypersensitivity states. Pain 1991;44:293-9.

14. Seltzer Z, Cohn S, Ginzburg R, Beilin B. Modulation of neuropathic pain behavior in rats by spinal disinhibition and NMDA receptor blockade of injury discharge. Pain 1991;45:69-75.

15. Yamamoto T, Yaksh TL. Comparison of the antinociceptive effects of pre and posttreatment with intrathecal morphine and MK 801, an NMDA antagonist on the formalin test in the rat. Anesthesiology 1992;77:757-71.

16. Mao J, Price DD, Hayes RL, Lu J, Mayer DJ, Frenk H. Intrathecal treatment with dextrorphan or ketamine potently reduces pain-related behaviors in a rat model of peripheral mono-neuropathy. Brain Res 1993;605:164-8.

17. Kristensen JD, Karlsten R, Gordh T, Berge OG. The NMDA
In peripheral neuropathic pain syndromes, central sensitization is well documented at the spinal cord level $(11,13,39,40)$, thanks to the animal peripheral neuropathic pain model (eg, tight ligature of the sciatic nerve in rat) (41). Unfortunately, animal models of central pain that could allow assessment of the effect of NMDA blockers involve spinal relays (42) but not thalamus or cortex.

The CPSP mechanism remains unclear. Several hypotheses have been proposed: a spinothalamic deficit (43-44), thalamic hyperactivity or loss of thalamic inhibition by lesions of the corticothalamic fibres (45-49). The mechanism by which ketamine produces analgesia in CPSP is also hypothetical. Ketamine-induced pain relief could be mediated by the NMDA receptors system, but there is, so far, no documented evidence of NMDA-related sensitization in CPSP. Another putative central system, such as bulbospinal pathways, may be involved (50).

The results of our preliminary study are as promising as the few other data in CPSP (33), but administration of ketamine in central pain management deserves placebo-controlled studies.

antagonist 3-(2-carboxypiperazin-4-yl) propyl-1-phosphonic acid (CPP) has antinociceptive effect after intrathecal injection in the rat. Pain 1994;56:59-67.

18. Greenamyre JT, Young AB, Penney JB. Quantitative autoradiographic distribution of $\mathrm{L}-\left({ }^{3} \mathrm{H}\right)$ glutamate-binding sites in the rat central nervous system. J Neurosci 1984;4:2133-44.

19. Monaghan DT, Cotman CW. Distribution of N-methyl-D-aspartate-sensitive L- $\left({ }^{3} \mathrm{H}\right)$ glutamate-binding sites in rat brain. J Neurosci 1985;5:2909-19.

20. Jansen KL, Faull RL, Dragunow M, Waldvogel H. Autoradiographic localisation of NMDA, quisqualate and kainic acid receptors in human spinal cord. Neurosci Lett 1990;108:53-7.

21. Collingridge GL, Singer W. Excitatory amino acid receptors and synaptic plasticity. Trends Pharmacol Sci 1990;11:290-6.

22. Salt TE, Eaton SA. Function of non-NMDA receptors and NMDA receptors in synaptic responses to natural somatosensory stimulation in the ventrobasal thalamus. Exp Brain Res 1989;77:646-52.

23. Salt TE, Eaton SA. Sensory excitatory postsynaptic potentials mediated by NMDA and non-NMDA receptors in the thalamus in vivo. Eur J Neurosci 1991;3:296-300.

24. Church J, Lodge D. N-methyl-D-aspartate (NMDA) antagonism is central to the actions of ketamine and other phencyclidine receptor ligands. In: Domino EF, ed. Status of Ketamine in Anesthesiology. Ann Arbor: NPP Books, 1990:501-19.

25. Yamamura T, Harada K, Okamura A, Kemmotsu O. Is the site of ketamine anaesthesia the N-methyl-D-aspartate receptor? Anesthesiology 1990;72:704-10.

26. Domino EF, Chodoff P, Corssen G. Pharmacologic effects of CI. 581 a new dissociative anaesthetic in man. Clin Pharmacol Ther 1965;6:279-91.

27. Domino EF. Ketamine: isomers and metabolites. Excerpta Medica 1980;538:696-9.

28. Bovill JG, Dundee JW. Alterations in response to somatic pain associated with anaesthesia-ketamine. Br J Anaesth 1971;43:496-9.

29. Sadove MS, Shulman M, Hatano S, Fevold N. Analgesic effects of ketamine administered in subdissociative doses. Anesth Analg 1971;50:452-7.

30. Caro DB. Trial of ketamine in an accident and emergency department. Anaesthesia 1974;29:227-9.

31. Clements JA, Nimmo WS. The pharmacokinetics and analgesic effect of ketamine in man. Br J Anaesth 1981;53:27-31.

32. Grant IS, Nimmo WS, Clements JA. Pharmacokinetics and analgesic effects of IM and oral ketamine. Br J Anaesth 1981;53:805-9.

33. Backonja M, Arndt G, Gombar KA, Check B, Zimmermann M. Response of chronic neuropathic pain syndromes to ketamine: a preliminary study. Pain 1994;56:51-7.

34. Stannard CF, Porter GE. Ketamine hydrochloride in the treatment of phantom limb pain. Pain 1993;54:227-30.

35. Oye I, Mathisen L, Skjelbred P. Studies on effect of ketamine 
analgesia in neuropathic pain. $7^{\text {th }}$ World Congress on Pain, Paris, 1993:195. (Abst 536)

36. Mathisen LC, Skjelbred P, Skoglund LA, Oye I. Effect of ketamine, an NMDA receptor inhibitor, in acute and chronic orofacial pain. Pain 1995;61:215-20.

37. Eide PK, Stubhaug A, Oye I, Breivik H. Continuous subcutaneous administration of the N-methyl-D-aspartic acid (NMDA) receptor antagonist ketamine in the treatment of post-herpetic neuralgia. Pain 1995;61:221-8.

38. Andersen OK, Felsby S, Nicolaisen L, Bjerring P, Jensen TS, Arendt-Nielsen L. The effect of ketamine on stimulation of primary and secondary hyperalgesic areas induced by capsaicin - A double blind, placebo controlled, human experimental study. Pain 1996;66:51-62.

39. Dubner R. Neuronal plasticity and pain following peripheral tissue inflammation or nerve injury. In: Blond MR, Charlton JE, Woolf CJ, eds. Pain Research and Clinical Management, vol 4. Proceedings of the VIth World Congress on Pain. Amsterdam: Elsevier, 1991:263-76.

40. Coderre TJ, Katz J, Vaccarino AL, Melzack R. Contribution of central neuroplasticity to pathological pain: review of clinical and experimental evidence. Pain 1993;52:229-85.

41. Bennett GJ, Xie YK. A peripheral mononeuropathy in rat that produces abnormal pain sensation like those seen in man. Pain 1988;33:87-107.

42. Xu GJ, Hao J-X, Aldskogius H, Seiger A, Wiesenfield-Hallin Z. Chronic pain-related syndrome in rats after ischemic spinal-cord lesion: a possible animal model for pain in patients with spinal cord injury. Pain 1992;48:279-90.

43. Boivie J, Leijon G, Johansson I. Central post-stroke pain: a study of the mechanisms through analysis of the sensory abnormalities. Pain 1989;36:173-85.

44. Andersen G, Vestergaard K, Ingeman-Nielsen M, Jensen TS. Incidence of central post-stroke pain. Pain 1995;61:187-93.

45. Cesaro P, Mann MW, Moretti JL, et al. Central pain and thalamic hyperactivity: a single photon emission computerized tomographic study. Pain 1991;47:329-36.

46. Rinaldi PC, Young RF, Albe-Fessard D, Chodakiewitz J. Spontaneous neuronal hyperactivity in the medial and intralaminar thalamic nuclei of patients with deafferentation pain. J Neurosurg 1991;74:415-21.

47. Jeanmonod D, Magnin M, Morel A. Thalamus and neurogenic pain: physiological, anatomical and clinical data. Neuroreport 1993;4:475-8.

48. Lenz FA, Seike M, Lin YC, et al. Neurons in the area of human thalamic nucleus ventralis caudalis respond to painful heat stimuli. Brain Res 1993;623:235-40.

49. Lenz FA, Kwan HC, Martin R, Tasker R, Richardson RT, Dostrovsky JO. Characteristics of somatotopic organization and spontaneous neuronal activity in the region of the thalamic principal sensory nucleus in patients with spinal cord transection. J Neurophysiol 1994;72:1570-87.

50. Pekoe GM, Smith DJ. The involvement of opiate and monoaminergic neuronal systems in the analgesic effects of ketamine. Pain 1982;12:57-73. 


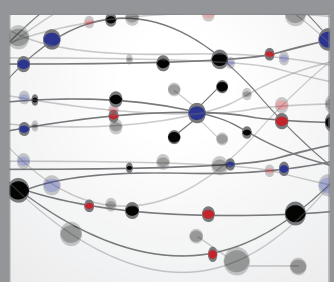

The Scientific World Journal
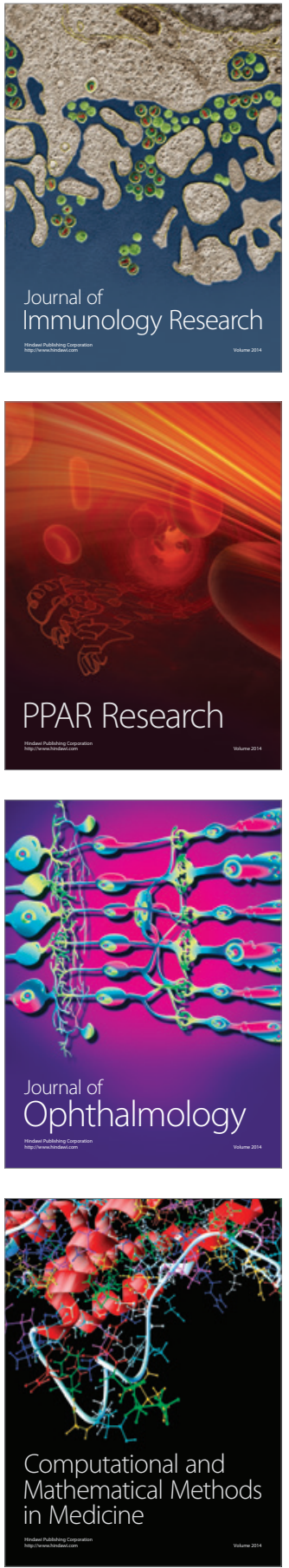

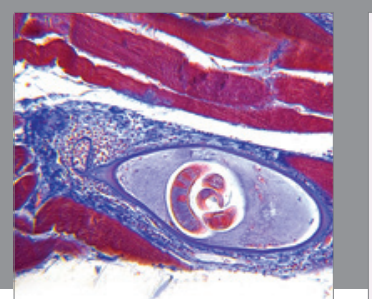

Gastroenterology Research and Practice

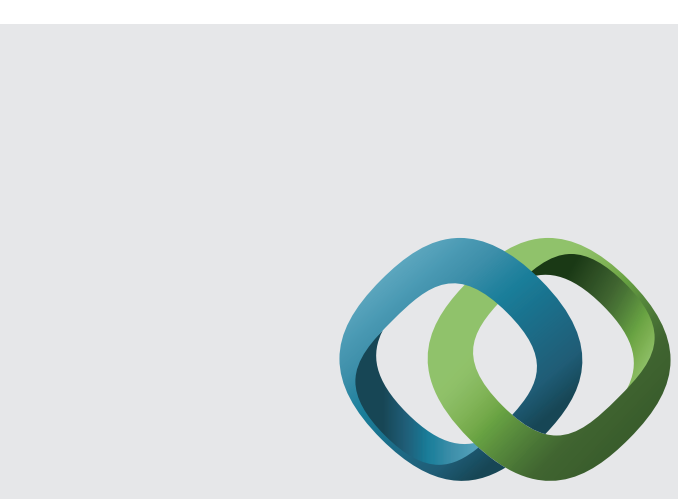

\section{Hindawi}

Submit your manuscripts at

http://www.hindawi.com
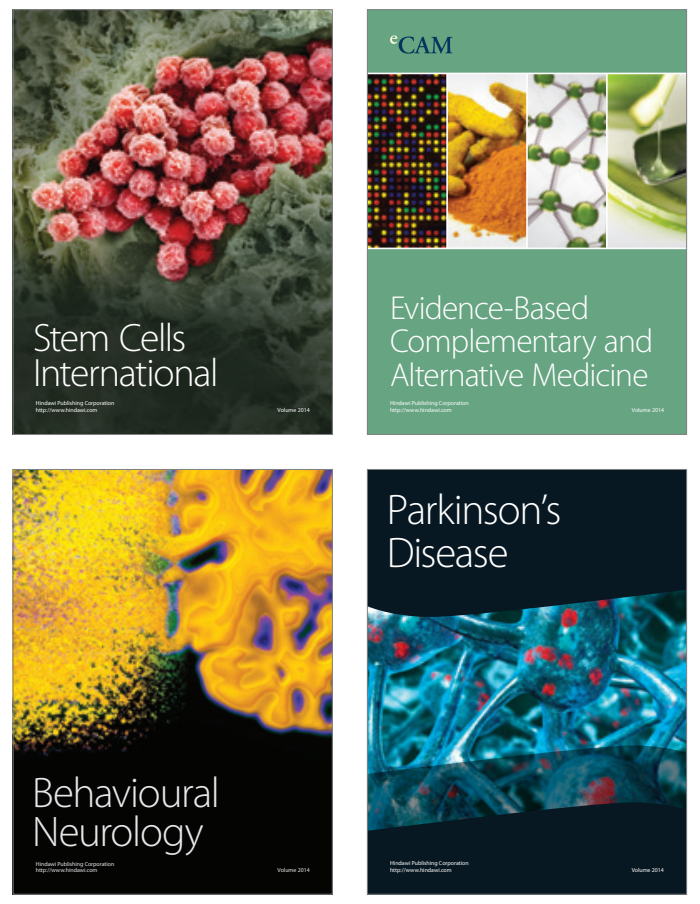
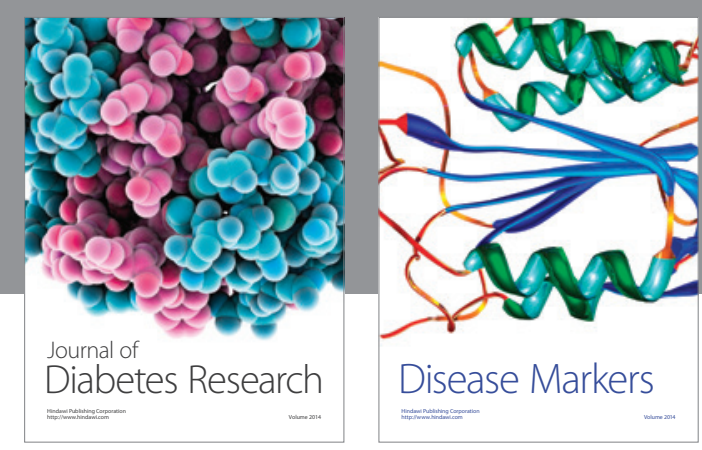

Disease Markers
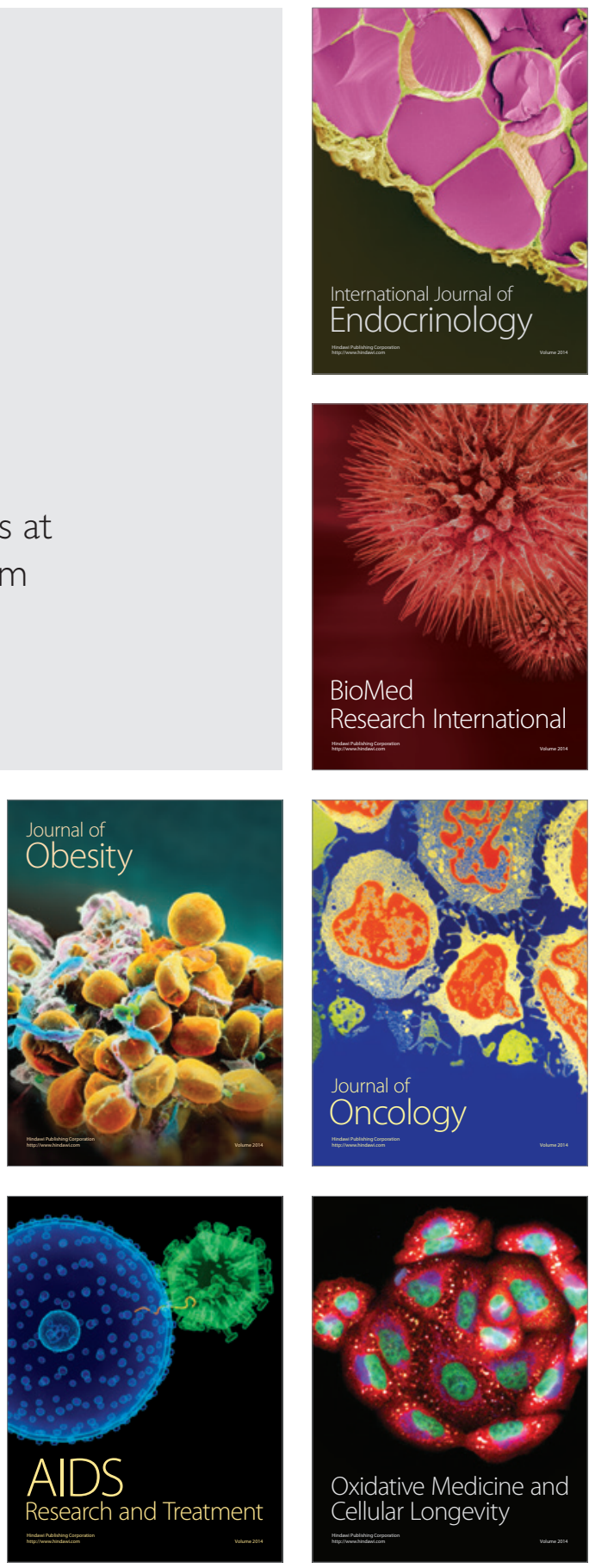